\title{
ROADS ACCESIBILITY TO AGRICULTURAL CROPS USING GIS TECHNOLOGY. METHODOLOGICAL APROACH
}

DOI: $10.21163 / G T \_2018.132 .02$

\author{
Ştefan BILAŞCO ${ }^{12}$, Sanda ROŞCA ${ }^{1}$, Ioan PACURAR ${ }^{3}$, Nicolaie MOLDOVAN ${ }^{3}$, Iuliu \\ VESCAN ${ }^{I}$, Ioan FODOREAN ${ }^{1}$, Dănuţ PETREA ${ }^{I}$
}

\begin{abstract}
:
The access to agricultural fields represents the main factor which favours their spatial distribution and their mechanized exploitation. In addition to this it valorizes the fields by enabling their intensive cultivation, fast harvesting and product distribution to collecting, processing and sales centres, with a main impact on perishable goods. The short access time to perishable crops enables their delivery in large quantities to the market, without major losses, thus their value increases. The present study analyses the accessibility of agricultural lands included in the high class of favourability for agricultural use, based on GIS techniques, with the purpose of economically valorising the territory by identifying the lots with very good accessibility and high favourability determined by rational exploitation. The following analysis is performed in a highly agricultural area, polarised by three agricultural sales centres and characterised by a low density of European, national and county roads (which offer easy access) while there is a high density of village roads and direct roads to agricultural lots and crops. The methodology of study was structured in two interconnected stages: the SWOT analysis of the present situation in what concerns the road quality and the implementation of a GIS spatial analysis accessibility model based on integrated network analysis in order to identify the main sales centres and the allocation of each agricultural lot to a certain sales centre. Using this analysis, certain hypotheses and proposals were made for the economically valid cultivation of the land and its accessibility as well as for the identification of intermediary collecting and primary sales centres.
\end{abstract}

Key-words: Road accessibility, GIS model, Temporal accessibility, Crops favourability, Land evaluation, Crops management.

\section{INTRODUCTION AND STUDY AREA}

The quality and the constant maintenance of access roads leading to agricultural land are extremely important for the transportation of materials, machinery or workers. In the case of a poor maintenance, it determines various difficulties in moving the machinery, possible higher fuel consumption and thus, the damaging of the used vehicles (Blarel et al., 1992; Handy \& Niemeier, 1997; Jaarsma, 2000; Wiggins \& Proctor, 2001; Castella et al., 2005; Păcurar \& Buta, 2007; Muntele et al., 2010; Páez et al., 2012; Iimi et al., 2015; Hartvigsen, 2016; Janus et. al., 2017).

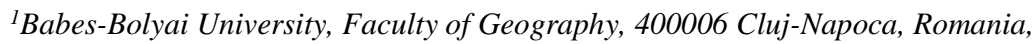
stefan.bilasco@ubbcluj.ro, sanda.rosca@ubbcluj.ro,iuliu.vescan@ubbcluj.ro, ioan.fodorean@ubbcluj.ro;

${ }^{2}$ Romanian Academy, Cluj-Napoca Subsidiary Geography Section, 400015 Cluj-Napoca, Romania;

${ }^{3}$ University of Agricultural Science and Veterinary Medicine Cluj-Napoca, 5400372 Cluj-Napoca, Romania, ioanpacurarcj@yahoo.com;
} 
Considering the role of roads as access routes to agricultural lots, they influence considerably the evaluation of the land for various agricultural uses (Ajiboye, 1994; Janus \& Taszakowski, 2015) as well as the evaluation of their economical favourability (Wang et al., 2010; Haidu \& Nicoară, 2011).

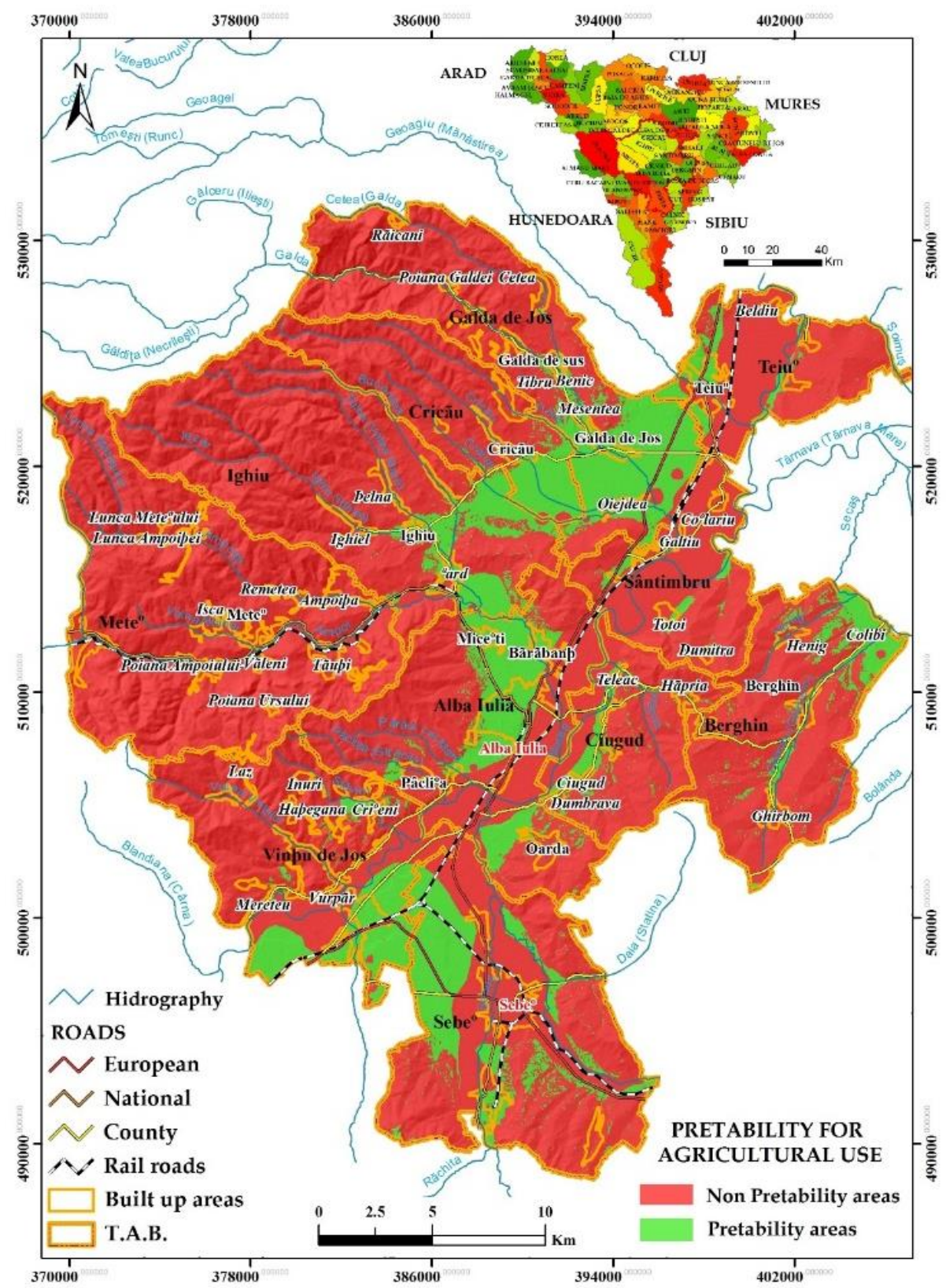

Fig. 1. Geographical position of the study area highlighting the favourability for agricultural use. 
As the present study highlights economical aspects, it also focuses on the role of the roads in facilitating the access for transport and distribution.

The accessibility of agricultural lots to the main roads reduces the average time of placing the crops on the outlet market as well as the additional costs associated to the production of crops and agricultural works (Curtis \& Scheurer, 2010; Dumitru et al., 2010; Bilașco et al., 2016).

In order to reach the objectives of this study, GIS technology was used to identify the agricultural favourability of various agricultural lots (Van Diepen, 1991; Halder, 2013; Roșca, 2015a,b; Moldovan et al., 2016) as well as the identification of their temporal accessibility (Thapa \& Murayama, 2008; Oprea, 2011; Ivan \& Haidu, 2012; Vega, 2012; Rusu et al., 2013; Nicoară \& Haidu, 2011; Nicoară \& Haidu, 2014; Man et al., 2015; Bobkova \& Holesinska, 2017).

The study area is represented by the Alba Iulia Association for Intercommunity Development (AIDA) which includes 11 administrative units totalizing $936 \mathrm{~km} 2$ (14.9\% of the total surface of Alba County) (Fig. 1). Its functionality is based on the identification of favourability elements with the main purpose of increasing the economic prosperity and the quality of the inhabitants from this area (Moldovan, 2016). The favourability for agricultural crops has been identified in a previous study as an average between the favourability for the cultivation of wheat, barley, corn, beetroot, potato, peas-beans and sunflower, the favourability classes being determined by climatic, hydrological, pedological and geomorphologic conditions (Fig. 1).

\section{METHODOLOGY}

The analysis of land accessibility was performed through an integrated study which is based on the analysis and identification of acces road quality and the implementation of a spatial analysis GIS model which spatially identifies the acces time to the analised agricultural lots (Fig. 2). In this respect a spatial database was created to include the areas facourable for agricultural crops and the territorial position of the main consumption and distribution centres. The numerical database which is included in the spatial analysis model is represented by the maximum speed attainable on different road categories.

The spatial database represents the basis for the development of the spatial analysis model which is concerned with accessibility and the computation of access time in minutes to the main storage and consumption centres, as well as the allocation of land lots based on these time intervals to certain centres for storage and consumption.

The purpose of this study is directed towards highlighting the economical efficiency of the agricultural lands. This is done, on the one hand, in order to identify the closest lots to the consumtion centres (maximum accessibility, minimum access time, minimum accessibility, maximum access time) and, on the other hand, to make proposals for the establishment of intermediary centres for storage and occasional sale of the products. This is based on the allocation of agricultural lots to certain sales and consumption centres, the SWOT analysis of the access ways and the maximum access time intervals. 


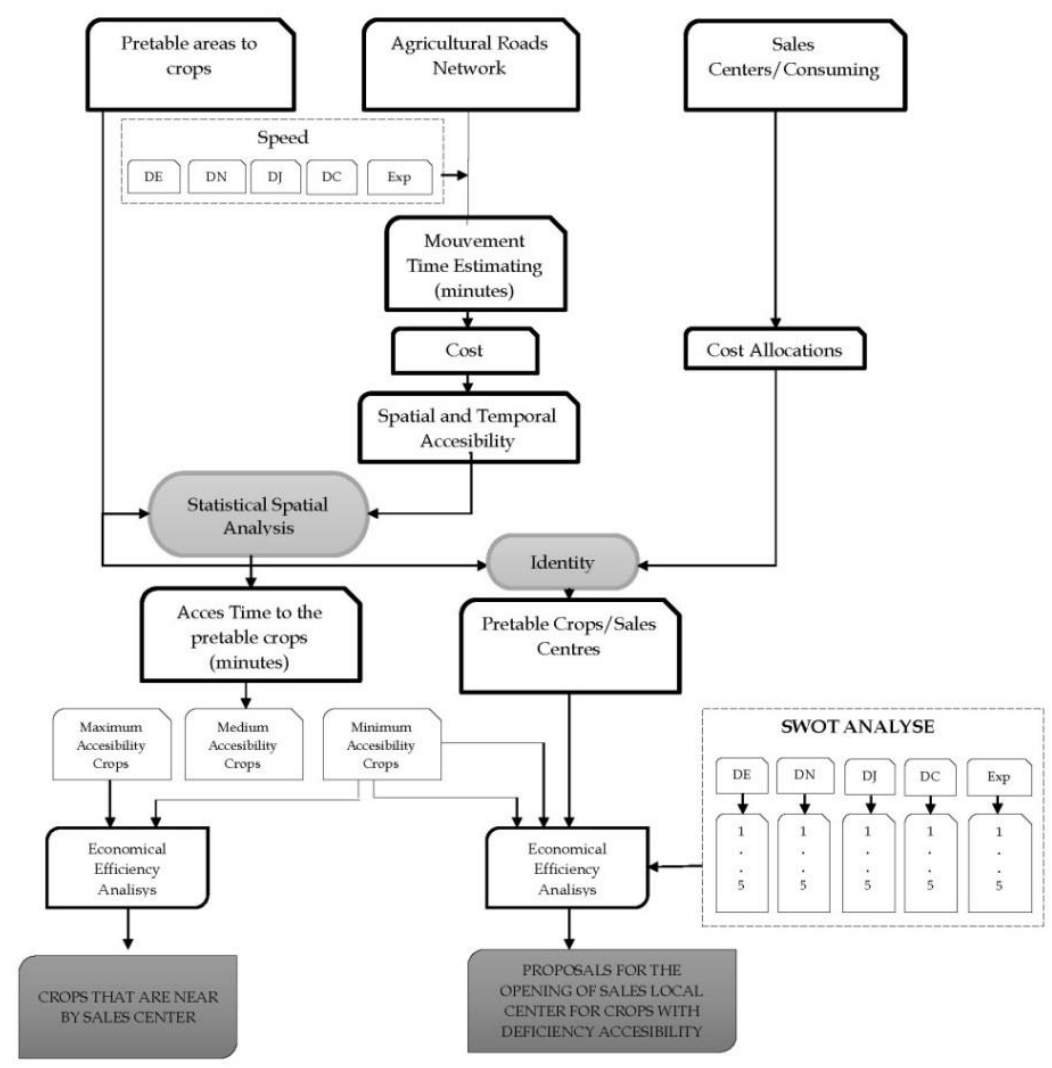

Fig. 2. Flow chart of applied G.I.S. analysis for roads accessibility in agricultural areas.

\section{RESULTS}

\subsection{A model of temporal accessibility of agricultural lands}

The accessibility of agricultural lands represents a highly important aspect in the management, exploitation and capitalisation on their specific agricultural products. The evaluation of temporal accessibility represents an important stage as the development of agriculture is of capital importance in the present European context. The main focus is laid on the development of ecological agriculture based on classical-modern technological processes and on the sale of the resulted products as quickly as possible through the local collecting centres and the regional sales centres.

The identification of the specific access time to the agricultural lots was performed using a GIS model which was developed with a specific database (Table 1) which puts a spotlight on the road infrastructure as a main facilitator for the access to the production lots and the local and regional sales centres.

The evaluation of accessibility was made using raster databases derived from vector databases considering the fact that the road infrastructure is not represented on the whole study area. For this, the maximum access speed to the agricultural lots was considered to be $10 \mathrm{~km} / \mathrm{h}$ where the road infrastructure is absent (fields, hills). 
Table 1

Structure of the database

\begin{tabular}{|c|c|c|c|c|c|c|c|c|c|}
\hline $\mathrm{Nr}$ & Database & Type & \multicolumn{6}{|c|}{ Attribute } & $\begin{array}{c}\text { Database } \\
\text { type }\end{array}$ \\
\hline \multirow{3}{*}{1.} & \multirow{3}{*}{ Roads } & \multirow{3}{*}{ vector } & \multicolumn{6}{|c|}{ Type, maximum speed } & \multirow{3}{*}{ primary } \\
\hline & & & Type & E & $\mathrm{DN}$ & DJ & $\mathrm{CO}$ & field & \\
\hline & & & $\begin{array}{l}\text { Speed } \\
(\mathrm{km} / \mathrm{h})\end{array}$ & $100 / 70 / 50$ & $90 / 50$ & $90 / 50$ & 30 & 10 & \\
\hline 2. & Built-up areas & vector & \multicolumn{6}{|c|}{ name } & primary \\
\hline 3. & $\begin{array}{l}\text { Limits of administrative } \\
\text { units }\end{array}$ & vector & \multicolumn{6}{|c|}{ name } & primary \\
\hline 4. & $\begin{array}{lrr}\text { Movement } & \text { speed } & \text { on } \\
\text { different road types } & \\
\end{array}$ & $\begin{array}{l}\text { Raster } \\
\text { (GRID) }\end{array}$ & \multicolumn{6}{|c|}{ minutes $/ \mathrm{m}^{2}$} & modelled \\
\hline 5. & Accessibility & $\begin{array}{l}\text { Raster } \\
\text { (GRID) }\end{array}$ & \multicolumn{6}{|c|}{ minutes } & modelled \\
\hline 6. & Allocated areas & $\begin{array}{l}\text { Raster } \\
\text { (GRID) }\end{array}$ & \multicolumn{6}{|c|}{ Name of urban centre } & modelled \\
\hline
\end{tabular}

At the same time, the spatial analysis model took into consideration the built-up areas as barriers which limit the access. As the whole spatial analysis model is based on raster database structures, all built-up areas were excluded from these structures, thus the access would be calculated based only on the road types from the built-up area and their specific speeds.

The spatial analysis was performed on four levels, each of them relying on the previous inferior level or on the results from the spatial analysis of the inferior database levels.

The first stage consisted in identifying the time necessary to move through a raster cell from the grid resulting from the conversion of the vectors representing the road network. Taking into consideration the average width of a two-lane road, the resolution of $10 \mathrm{~m}$ was selected for the raster cell resulting from the vector-raster conversion.

Using the formula proposed by Julião (1999), Drobne (2003, 2005), Bilașco et al. (2015) the time necessary to cross one cell was calculated and expressed in minutes (Table 2):

$$
C C T=\frac{P S * 60}{T S * 1000},
$$

where: CCT - crossing time (minutes), PS - Pixel dimension, TS - Speed $(\mathrm{km} / \mathrm{h})$

Table 2

The maximum speed and the time required to cross a cell depending on the road type.

\begin{tabular}{|l|l|c|c|c|c|}
\hline \multirow{2}{*}{ Nr. } & \multirow{2}{*}{ Road type } & \multicolumn{4}{|c|}{$\begin{array}{l}\text { Speed } \\
\mathbf{k m} / \mathbf{h})\end{array}$} \\
\cline { 3 - 6 } & & \multicolumn{2}{|c|}{ Built-up areas } & \multicolumn{2}{c|}{ Outside the built-up areas } \\
\cline { 3 - 6 } & & Speed & Time (minutes) & Speed & Time (minutes) \\
\hline 1 & European & $70 / 50$ & $0.0085 / 0.012$ & 100 & 0.006 \\
\hline 2 & National & 50 & 0.012 & 90 & 0.0066 \\
\hline 3 & County & 50 & 0.012 & 90 & 0.0066 \\
\hline 4 & Communal & 30 & 0.02 & 30 & 0.02 \\
\hline 5 & Field & - & - & 10 & 0.06 \\
\hline
\end{tabular}




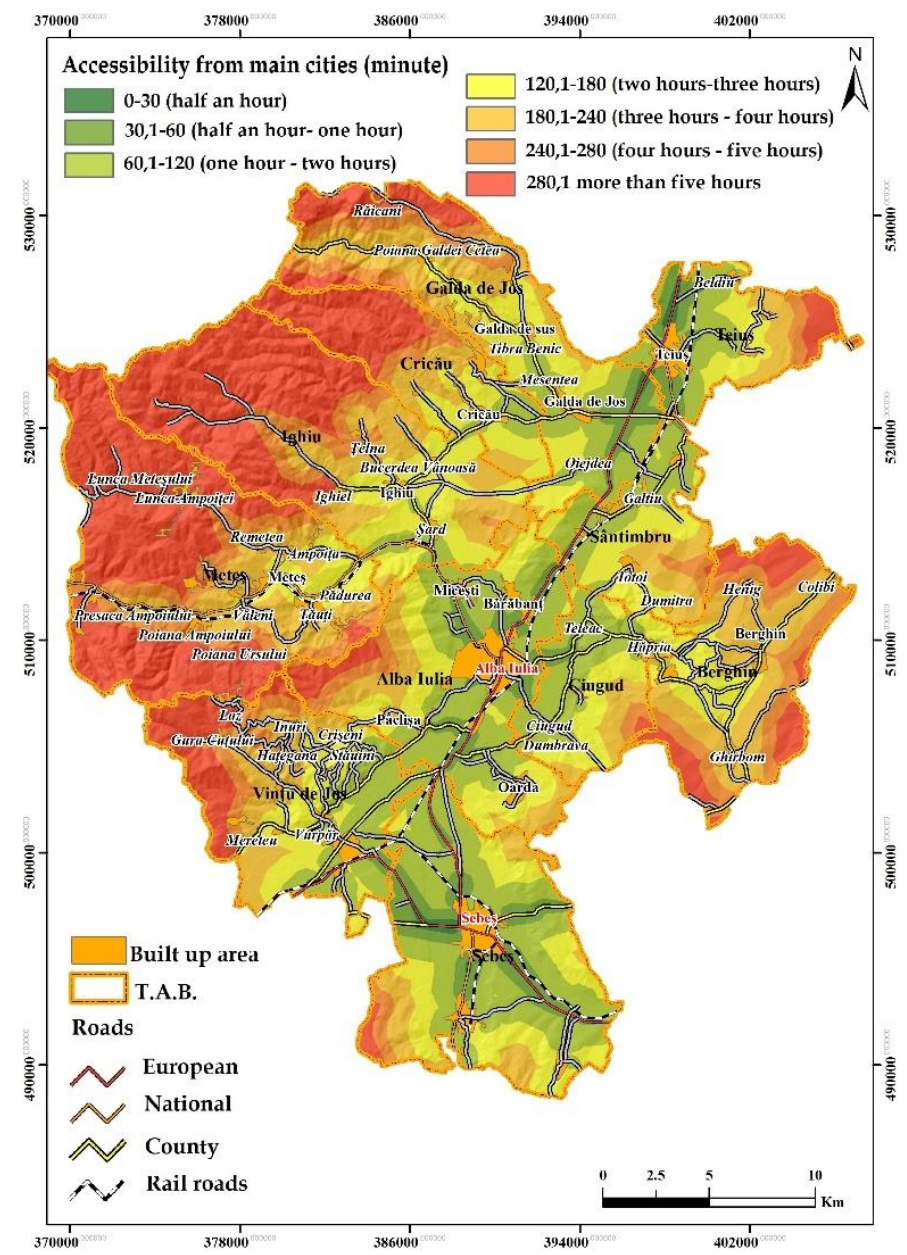

The second stage consists in modelling the access time to the main local and regional collecting centres for the entire study area, having as a support for the spatial analysis the modelled database which resulted from calculating the time required to cross one cell of the raster. In this case only the sales centres Alba Iulia, Teiuş and Sebeș were considered.

Using geoinformatic softwares and the spatial analysis functions cost distance which enable the identification of the shortest route using the time required for crossing a raster cell, the access time to the closest regional sales point was calculated considering the speed of moving the products and thus, the access (Fig. 3).

Fig. 3. Temporal accessibility map for the main towns, in minutes.

By analysing the results from this stage of the spatial modelling process one notices the very good accessibility of the agricultural lands from the Mureş valley and from the river's close vicinity (maximum access time of 1 hour), due to a very well developed road network represented by the fast transport network (European, national and county roads) and a highly dense network of acces roads to agricultural lands (communal and agricultural exploitation roads).

One also notices the fact that there is a relatively good access from all the built-up areas of the administrative units (maximum 2-3 hours) to the regional sales centres, which highlights their role as secondary sales centres and storage centres for product sale in the regional centres.

In addition to the density of different types of roads, another important factor which influences the access to agricultural lands is represented by topography. This acts as a 
restrictive factor in what concerns the development of secondary and primary access roads to agricultural lots (exploitation roads) as well as the direct access of agricultural machines. Two specific situations are highlighted in this respect: the areas from the river valley and low hills with very good accessibility (maximum 180 minutes) and the lots from the high hills and the montaneous area with an accessibility ranging between 3-5 hours and more than 5 hours.

Once the access time in minutes had been identified for the entire study area in reference to the regional sales centres, the next step was to identify the areas which gravitate towards one or more of these centres, which represented the third stage in the modelling process.

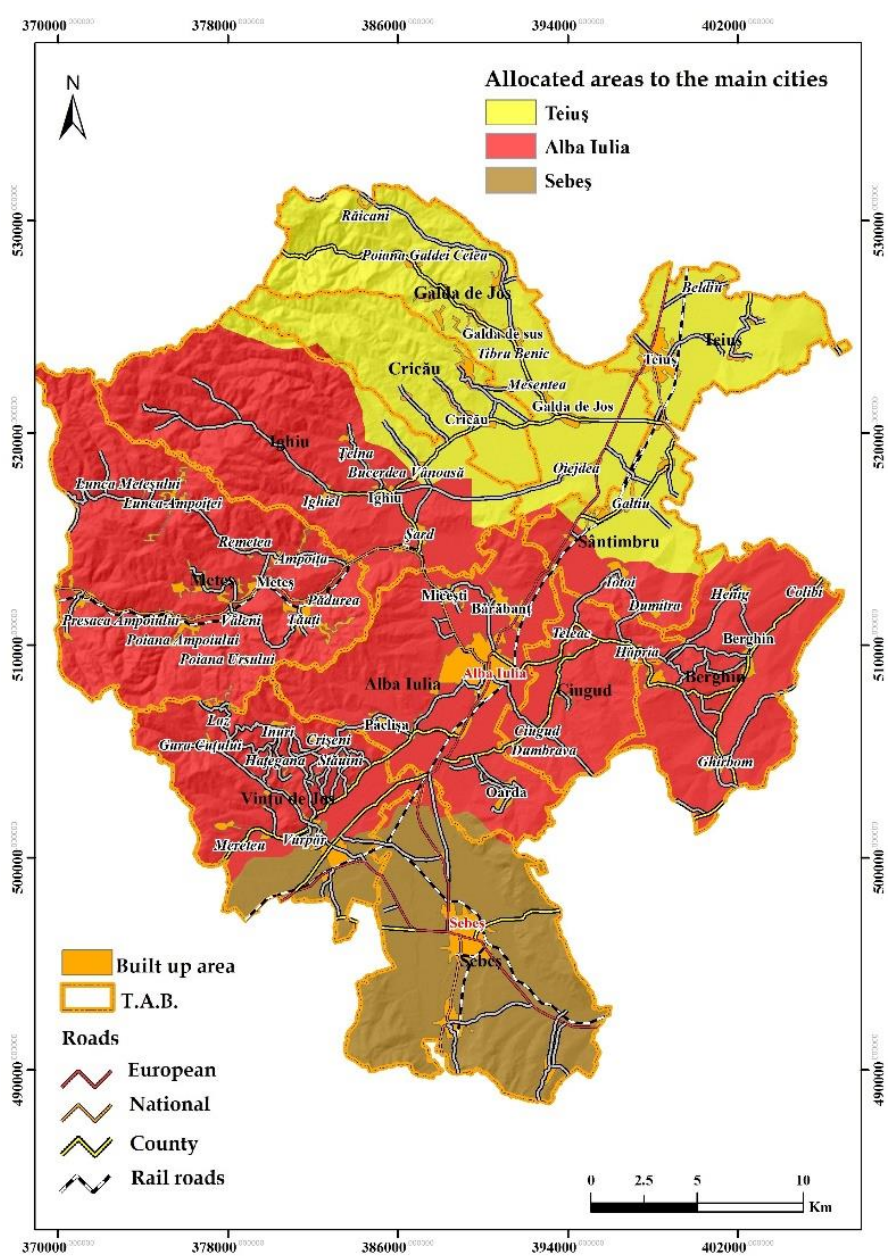

Taking into consideration the fact that the transportation time of the agricultural products is very important due to their perishable characteristics, the identification of the sales centre to which each agricultural lot is allocated is a very important objective.

The identification of the areas allocated to a specific sales centre was performed by using spatial analysis with raster and vector structures and applying the function Cost Allocation, which enables the identification of the areas which are allocated to a certain point by considering the shortest access time to that point.

Thus, the areas which gravitate towards the regional sales points represented by the towns Teius,, Alba Iulia and Sebeș, were identified (Fig. 4).

Fig. 4. Map of the areas allocated to the main towns.

The analysis of the results highlights the city Alba Iulia as the main regional sales centre, with an allocated area of approximately $60 \%$ of the whole territory, followed by Teius, with approximately $25 \%$ of the whole territory and Sebeș, with a smaller area, 
representing approximately $13 \%$ of the whole territory. This small value is explained by the role of the town of Sebeș as outskirts of Alba Iulia.

As a study case for exemplifying and identifying the accessibility to agricultural lots we considered the suitable lots for agricultural crops by using morphometric and risk parameters (Bilașco et al., 2016).

By analysing the static characteristics of the lots allocated to the main sales centres, one notices the spatial extension of a suitable and unitary lot which stretches over the surface of 4 administrative units (Teiuş, Garda de Jos, Cricău, Ighiu), with 4007 hectars, which reunites most of the agricultural lands of the 4 administrative units.

A similar situation is noticed in the case of a unitary suitable lot allocated to the town of Sebeș, which extends over the surface of two administrative units and is located mainly

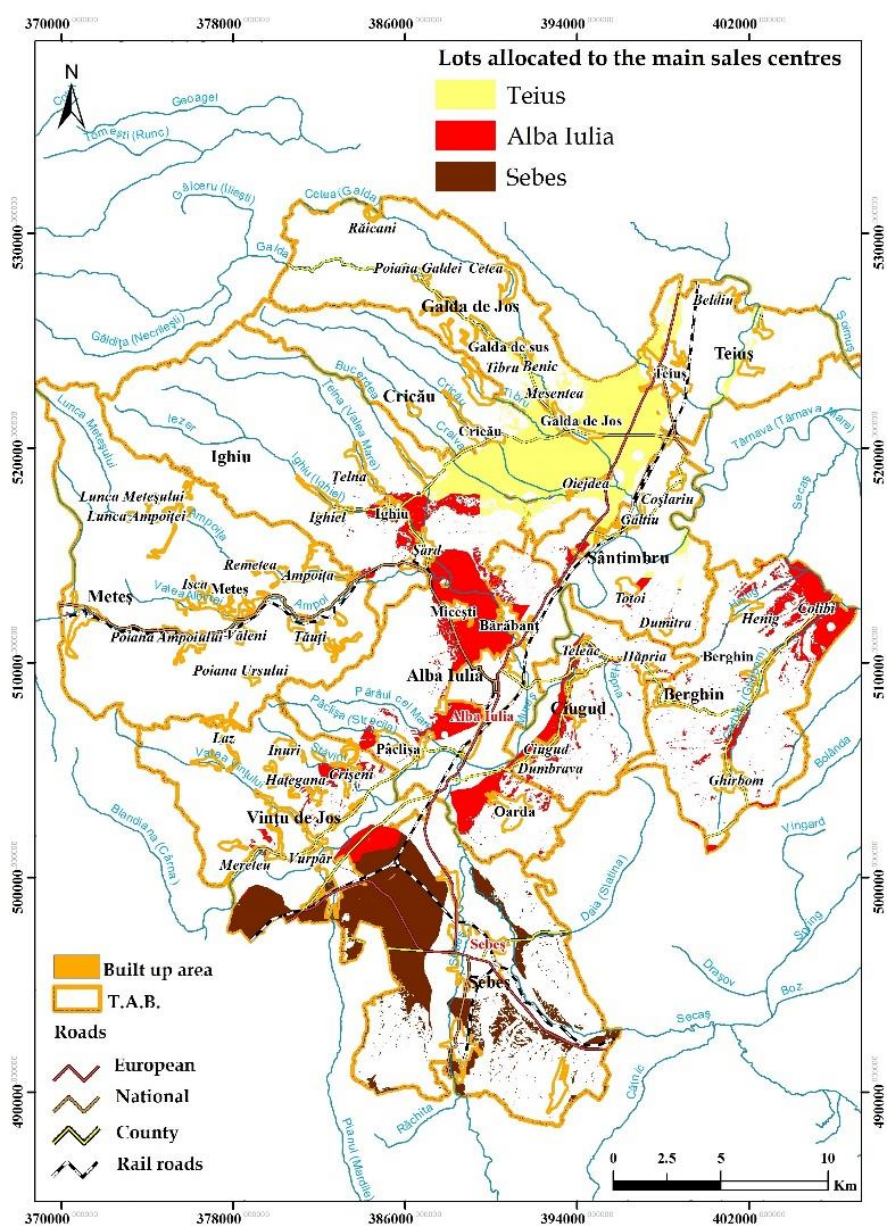
in the valley of the Mureș and its left tributary, the Seceșul.

In what concerns the suitable lots allocated to the city of Alba Iulia, 3 unitary lots with large surfaces are highlighted: firstly, the lot which is situated in the $\mathrm{N}$ and the NV of the city and territorialy overlaps the agricultural lands cultivated mainly with vegetables and cereals which can supply the local city markets. Secondly, one can notice the high territorial extension of the suitable lots which had been allocated to the city of Alba Iulia and are located at the contact between the hilly sector and the Mureș floodplain, these lots being connected by a very good road network, a fact that determines a very good accessibility.

Fig. 5. Map of agricultural lots allocated to the main sales centres.

Thirdly, the lots situated in the area of low hills from the Întresecașe plateau are mainly used for cereal crops. The suitable unitary lots with very large surfaces will influence both the production and its estimated value. At present, overfragmenting the lots represents one 
of the main problems which arise when a certain favourable crop is planned according to the specific characteristics of the analysed territory.

Table 3.

Statistic characteristics of the lots allocated to the main sales centres

\begin{tabular}{|l|c|c|c|c|c|}
\hline \multirow{2}{*}{ The main sales centres } & \multicolumn{4}{|c|}{ Surface (ha) } & \multirow{2}{*}{$\begin{array}{c}\text { No. } \\
\text { Of lots }\end{array}$} \\
\cline { 2 - 6 } & Minim & Maxim & Medium & Sum & 768 \\
\hline Aiud & 0.5 & 4007 & 5.96 & 4582.36 & 768 \\
\hline Alba Iulia & 0.3 & 2097 & 2.02 & 4879.89 & 2415 \\
\hline Sebeș & 0.6 & 2776 & 4.29 & 3870.74 & 901 \\
\hline
\end{tabular}

For a better management of the favourable areas for certain crops, it is recommended to do microscale studies on the surface of the unitary agricultural lot in order to identify the characteristics of each territorial ecological lots and to take the best decisions regarding the

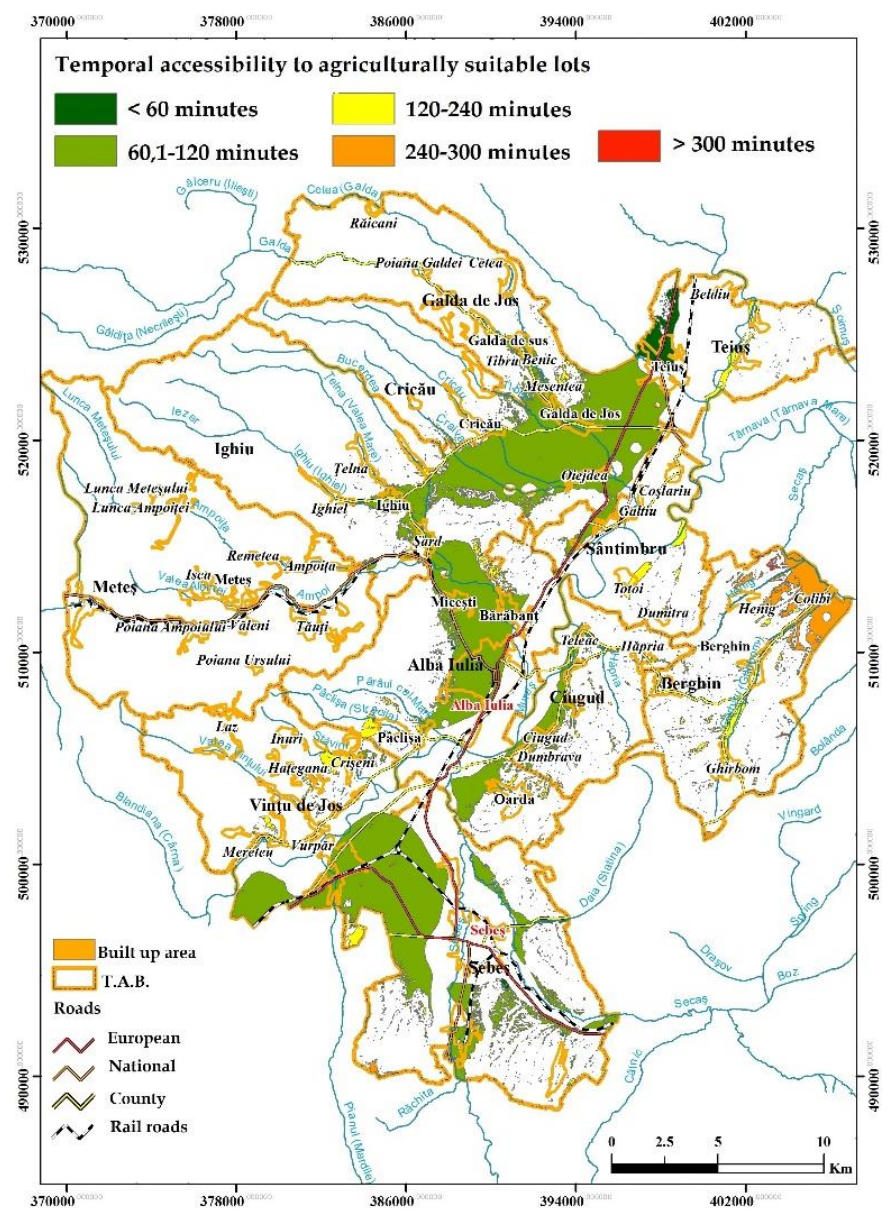

Fig. 6. Map of temporal accessibility to agriculturally suitable lots. choice of crop for that particular lot. The analysis performed on the average access time values to the agriculturally suitable lots highlights the very good accessibility (between 60 and 120 minutes) of approximately $91 \%$ of the analysed lots. One must notice that the large unitary lots are included in this category, which makes their use for perishable crops possible as the products can be sold in the main urban centres.

In the class of medium accessibility (240-300 minutes) there are, predominantly, the agricultural lots which are located on the outskirts of the study area, due to the scarce access infrastructure and in some places to a lack of it. 
The unitary lot with a large surface identified on the administrative unit of Berghin is included in this class and is located at the limit of the study area. It is connected only to a county road which ensures its access from the main sales centre of Alba Iulia. In these case it is recommended to make secondary and local centres for collecting the crops from these lands or to plant other cultures which correspond to the suitability of the land and which produce crops with a low perishable degree, in order to be able to store them for a longer period of time.

\subsection{SWOT analysis of road quality}

In order to capture in categories and types the influence of road presence/absence and road quality over the exploitation possibilities of the agricultural lands from the study area, the SWOT analysis was used.

This method has been used since 1971 by Ken Andrew (Horvath, 2008,) graphically and numerically expresses strong and weak points, at the same time evaluating the opportunities for development, as well as the threats. In this case the strong points were analysed as advantages, the weak points as disadvantages, the present and potential dangers were also analysed in classes of road categories and the opportunities were used as specific proposals.

The SWOT analysis was used to make the inventory and the evaluation of the development possibilities for the studied region as complex as possible, considering the road density and road quality (Table 4).

Table 4.

SWOT analysis of roads.

\begin{tabular}{|c|c|c|c|}
\hline \multicolumn{4}{|l|}{ EUROPEAN ROADS } \\
\hline & Importance & $\begin{array}{l}\text { Requenc } \\
\mathrm{y}\end{array}$ & $\begin{array}{l}\text { Magni } \\
\text { tude }\end{array}$ \\
\hline \multicolumn{4}{|l|}{ Strengths (S) } \\
\hline Ensures easy access to the main sales centres; & 5 & 1 & 5 \\
\hline High average driving speed; & 5 & 5 & 5 \\
\hline Easy access to the agricultural production units from the close vicinity; & 5 & 2 & 3 \\
\hline \multirow{2}{*}{$\begin{array}{l}\text { Good road quality; } \\
\text { Ensures regional competitivity. }\end{array}$} & 5 & 5 & 5 \\
\hline & 2 & 2 & 1 \\
\hline \multicolumn{4}{|l|}{ Weaknesses (W) } \\
\hline Limits entirely the access of agricultural machines; & 5 & 5 & 5 \\
\hline Inexistent access to the production units even in the case of a close vicinity; & 2 & 5 & 5 \\
\hline Constitutes barriers in the territorial extension of the lots; & 1 & 5 & 5 \\
\hline Difficult transport conditions for natural fertilisers; & 3 & 4 & 2 \\
\hline Restricted transport of chemical fertilisers. & 5 & 4 & 3.5 \\
\hline \multicolumn{4}{|l|}{ Opportunities (O) } \\
\hline Limited hourly access of agricultural machines; & 5 & 2 & 3 \\
\hline $\begin{array}{l}\text { Implementation of vegetation barriers for decreasing the vulnerability to pollution } \\
\text { by suspended dust and exhaust gases; }\end{array}$ & 5 & 5 & 5 \\
\hline Enables multiple acces points to local collecting points. & 5 & 1 & 3 \\
\hline \multicolumn{4}{|l|}{ Threats (T) } \\
\hline Major pollution degree; & 3 & 3 & 4.5 \\
\hline Major pollution risk; & 5 & 5 & 5 \\
\hline Major accident risk; & 2 & 1 & 1 \\
\hline Damaging of perishable products due to difficult access of transport vehicles. & 5 & 1 & 5 \\
\hline
\end{tabular}




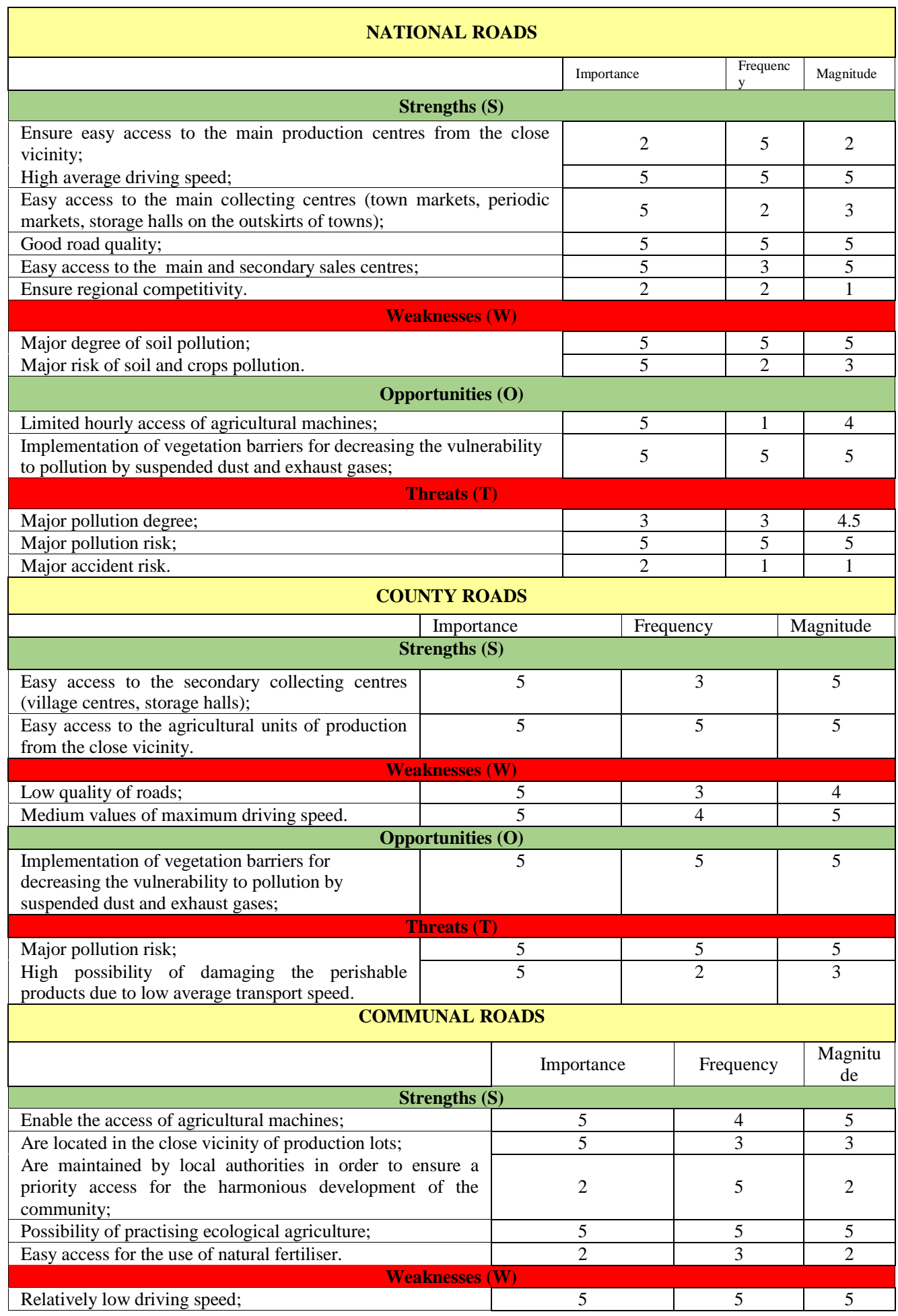




\begin{tabular}{|c|c|c|c|c|c|}
\hline Low quality. & \multicolumn{2}{|l|}{5} & 3 & \multicolumn{2}{|l|}{4} \\
\hline \multicolumn{6}{|l|}{ Opportunities (O) } \\
\hline $\begin{array}{l}\text { Exploitation of communal roads according to well } \\
\text { determined norms (weight, access); }\end{array}$ & \multicolumn{2}{|c|}{5} & 3 & \multicolumn{2}{|l|}{3} \\
\hline $\begin{array}{l}\text { Implementation of vegetation barriers for decreasing the } \\
\text { vulnerability to pollution by suspended dust and exhaust } \\
\text { gases; }\end{array}$ & \multicolumn{2}{|c|}{5} & 5 & \multicolumn{2}{|l|}{5} \\
\hline Threa & & & & & \\
\hline Major pollution risk; & \multicolumn{2}{|l|}{5} & 3 & \multicolumn{2}{|l|}{4} \\
\hline $\begin{array}{l}\text { Damaging of perishable products due to difficult access of } \\
\text { transport vehicles }\end{array}$ & \multicolumn{2}{|c|}{5} & 1 & \multicolumn{2}{|l|}{5} \\
\hline \multicolumn{6}{|c|}{\begin{tabular}{|c|} 
AGRICULTURAL EXPLOITATION ROADS \\
\end{tabular}} \\
\hline & & $\begin{array}{l}\text { Importanc } \\
\mathrm{e}\end{array}$ & $\begin{array}{l}\text { Frequenc } \\
\mathrm{y}\end{array}$ & \multicolumn{2}{|c|}{$\begin{array}{l}\text { Magnitu } \\
\text { de }\end{array}$} \\
\hline \multicolumn{6}{|c|}{ Strengths $(\mathbf{S})$} \\
\hline Ensure the direct access to the production lot; & & 5 & 5 & & 5 \\
\hline \multirow{2}{*}{\multicolumn{2}{|c|}{$\begin{array}{l}\text { Allow the access for all agricultural machines; } \\
\text { Are maintained by local authorities or by the farmer and their route can be } \\
\text { changed depending on the exploitation needs of the production units. }\end{array}$}} & 5 & \multicolumn{2}{|c|}{5} & 4 \\
\hline & & 5 & \multicolumn{2}{|c|}{5} & 3 \\
\hline \multicolumn{6}{|c|}{ Weaknesses (W) } \\
\hline \multicolumn{2}{|l|}{ Low maintenance state; } & 5 & \multicolumn{2}{|c|}{5} & 5 \\
\hline \multicolumn{2}{|l|}{ Low quality; } & 4 & \multicolumn{2}{|c|}{5} & 5 \\
\hline \multicolumn{2}{|l|}{ Low average driving speed; } & 2 & \multirow{2}{*}{\multicolumn{2}{|c|}{$\frac{5}{5}$}} & 3 \\
\hline \multicolumn{2}{|l|}{ Limited quantity of products being transported at once. } & 2 & & & 2 \\
\hline \multicolumn{4}{|l|}{ Opportunities (O) } & & \\
\hline \multirow{3}{*}{\multicolumn{2}{|c|}{$\begin{array}{l}\text { Development of the road system for ensuring accessibility to multiple lots; } \\
\text { Maintenance of roads by local authorities and the owners that use them. }\end{array}$}} & 5 & 4 & & 5 \\
\hline & & 5 & 5 & & 5 \\
\hline & & 3 & 5 & & 3 \\
\hline Threats (1) & & & & & \\
\hline $\begin{array}{l}\text { Fast degradation due to their maintenance regime an } \\
\text { exploitation; }\end{array}$ & & 5 & 5 & & 5 \\
\hline Fast obsolescence of agricultural machines due to their conditi & & 4 & 5 & & 4 \\
\hline Major accident risk due to urestricted animal access. & & 2 & 1 & & 2 \\
\hline
\end{tabular}

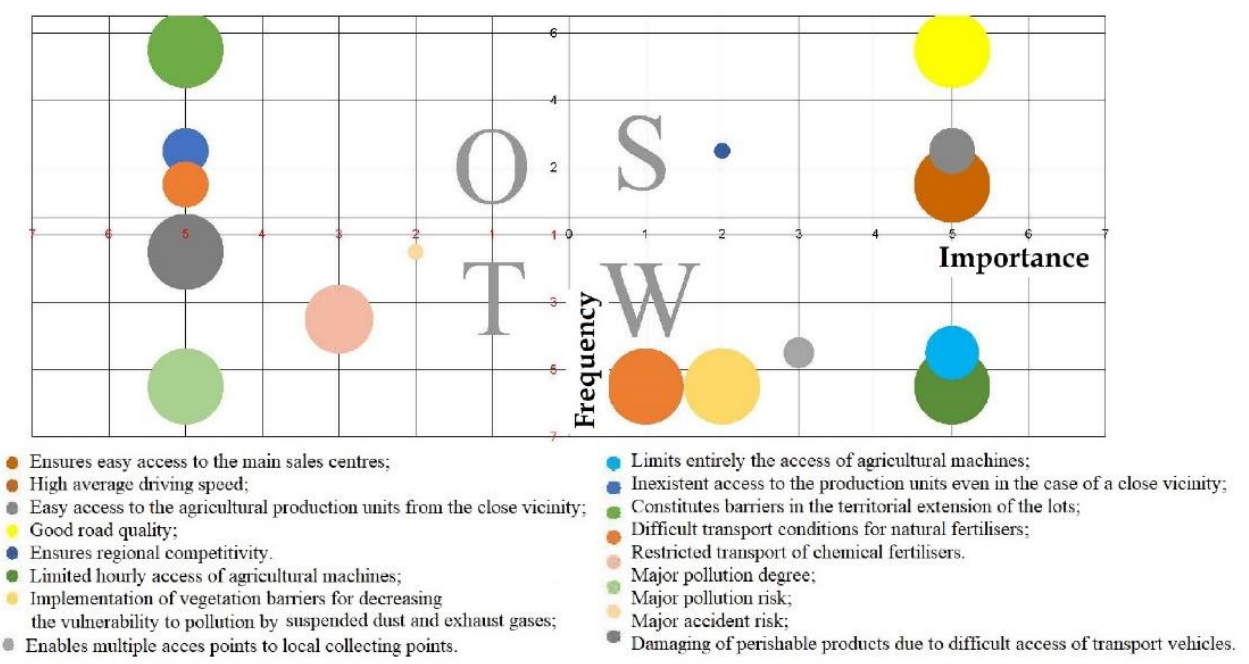

Fig. 7. SWOT evaluation for european roads. 


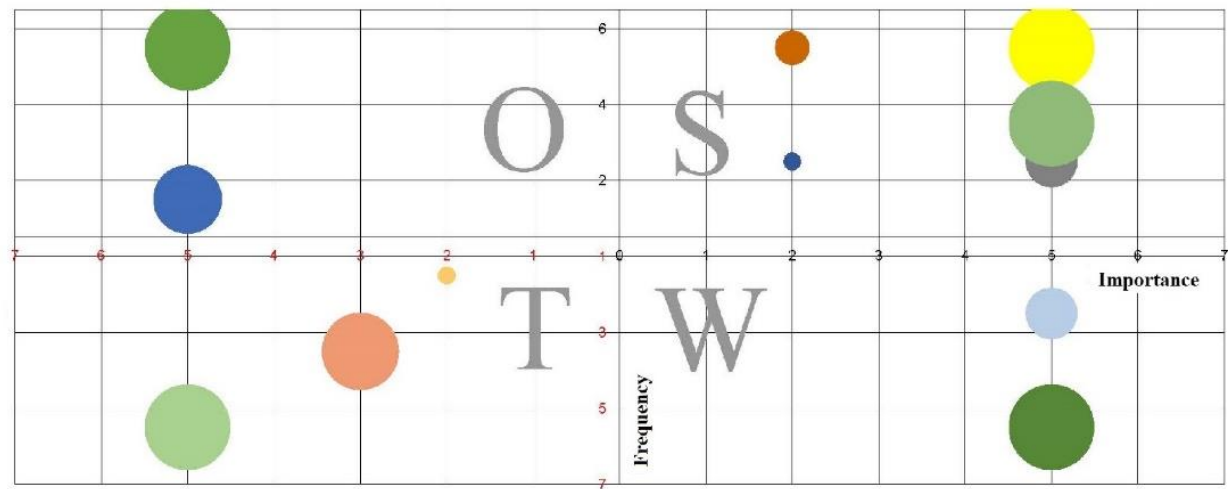

- Ensure easy access to the main production centres from the close vicinity; - High average driving speed;

- Easy access to the main collecting centres (town markets, periodic markets, storage halls on the outskirts of towns);

Good road quality;

- Easy access to the main and secondary sales centres;

- Ensure regional competitivity.

Limited hourly access of agricultural machines;

- Implementation of vegetation barriers for decreasing the vulnerability to pollution by suspended dust and exhaust gases;

- Major pollution degree;

- Major pollution risk:

Major accident risk.

- Limited hourly access of agricultural machines;

Fig. 8. SWOT evaluation of national roads.

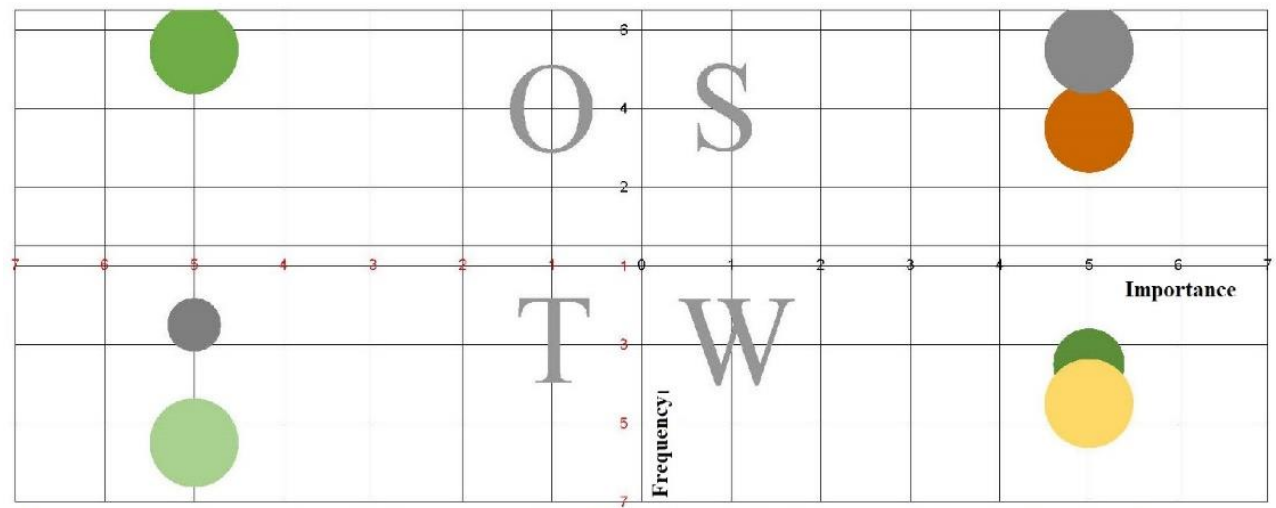

- Easy access to the secondary collecting centres (village centres, storage halls);

- Easy access to the agricultural units of production from the close vicinity.

- Low quality of roads;

- Medium values of maximum driving speed.

- Implementation of vegetation barriers for decreasing the vulnerability to pollution by suspended dust and exhaust gases;

- Major pollution risk;

- High possibility of damaging the perishable products due to low average transport speed.

Fig. 9. SWOT evaluation of county roads. 


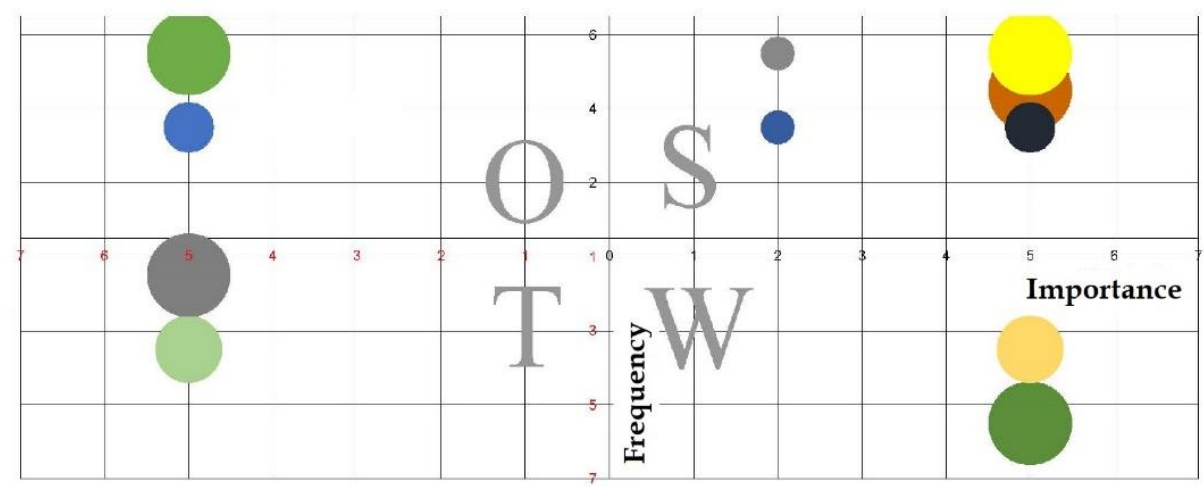

- Enable the access of agricultural machines;

- Are located in the close vicinity of production lots;

- Are maintained by local authorities in order to ensure a priority access for the harmonious development of the community;

Possibility of practising ecological agriculture;

- Easy access for the use of natural fertiliser.

- Relatively low driving speed;

Low quality.

- Exploitation of communal roads according to well determined norms (weight, access);

- Implementation of vegetation barriers for decreasing the vulnerability to pollution by suspended dust and exhaust gases;

- Major pollution risk;

- Damaging of perishable products due to difficult access of transport vehicles

Fig. 10. SWOT evaluation of communal roads.

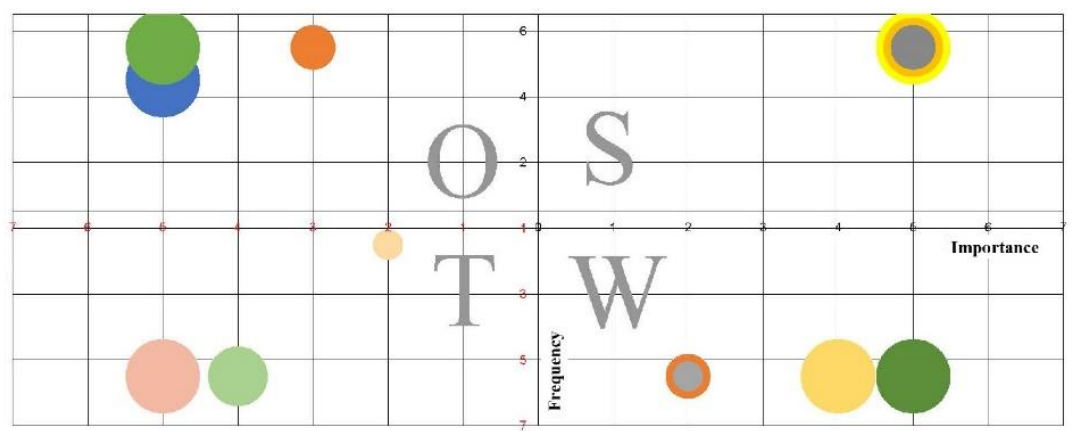

Ensure the direct access to the production lot;

- Allow the access for all agricultural machines:

- Limited quantity of products being transported at once.

- Are maintained by local authorities or by the farmer and their route can be changed depending on the exploitation needs of the production units.

Consolidation of roads for the access of modern transportation machines;

Low maintenance state;

- Low quality;

- Low average driving speed;

Development of the road system for ensuring accessibility to multiple lots:

- Maintenance of roads by local authorities and the owners that use them.

- Fast degradation due to their maintenance regime and intensive exploitation;

Fast obsolescence of agricultural machines due to their condition;

- Major accident risk due to urestricted animal access.

Fig. 11. SWOT evaluation of agricultural exploitation roads.

After performing the SWOT analysis, the main opportunities for the development of the Alba Iulia Association for Intercommunity Development were identified. These are the results of the facilities offered by the road network and make possible various proposals for the development of the production and sale of agricultural products.

The correspondence between the strengths and the opportunities of the region are in the quadrant I (SO). In quadrant II (WO) one notices the correspondence between weaknesses and opportunities, the degree in which the opportunities could or could not limit the 
influence of the weaknesses can be determined, as well as their possible transformation in strengths as a consequence of applying the specific proposals

Table 5.

Theoretical SWOT matrix.

\begin{tabular}{|c|c|c|}
\hline & $($ S-Streanghts $)$ & $($ W-Weaknesses $)$ \\
\hline$(\boldsymbol{O}$-Oportunities $)$ & SO & WO \\
\hline$(\boldsymbol{T}$-Threats $)$ & ST & WT \\
\hline
\end{tabular}

Quadrant III (ST) represents the relationship between strengths and threats and identifies the degree in which the threats could be reduced or eliminated as a consequence of using the identified strengths.

Quadrant IV (WT) highlights the relationship between weaknesses and threats and requires the analysis of their interdependence and the identification of possibilities of reducing the negative effects in the study area.

This evaluation consisted of giving a score for the importance, the frequency and the magnitude of each indicator included in the evaluation, with values ranging from 1 to 5 (Table 5).

The increase of economical efficiency for the agricultural lots with maximum suitability but low accessibility towards the main sales centres requires the identification of secondary centres for collecting and for primary sale. These would take over a part of the products and store them in qualitatively high storage conditions and facilitate their fast distribution. In order to capture the influence of the presence/absence and quality of roads in categories and types, the SWOT analysis was used as a main work method, its main purpose being the identification of a short delivery time for a large quantity of products.

The SWOT analysis was also used for a complex identification and evaluation of development possibilities as well as to identify the main collecting centres for the agricultural products depending on the density and the quality of roads from the study area (Table 4).

As a result of the integrated analysis of the time required to access an agricultural lot in the eastern part of the study area is highlighted. Here are suitable lots to which the access requires a long time (240-300 minutes) but which are viable in what concerns the opportunities offered by the road category. Thus, for an efficient exploitation from the point of view of transporting the agricultural products to the main sales centres we propose the development of a modern collecting centre in the Colibri village. The settlement finds itself in the category of easy access for road transportation towards all the sales centres as it is located at the junction between the county roads DJ107 and DJ107B, but it has low accessibility and sometimes no accessibility to production lots.

\section{CONCLUSION}

Agriculture is one of the main components supporting the national economy due to the fact that most of the land is suitable for cultivation. Efficient exploitation by selling on the market the products obtained through cultivation and land maintenance makes the economical value of the land to increase exponentially with the quantity of products which are harvested and sold. Leaving aside the agricultural maintenance of the lands, the access to them represents the main factor which gives additional value and determines low maintenance and exploitation costs where accessibility is very good. 
Using GIS spatial analysis models, the identification of access time, in minutes, to the agricultural lots with the highest suitability for cultivation has made possible the identification of the sales centres allocated to each lot and, thus, reducing the time required for transport between the production area and the main sales centre. In this way the costs of transport and distribution are minimised, as well as the risk of financial loss due to the alteration of perishable products.

Using the maximum travel speeds on road categories for the calculation based on the GIS spatial modeling of the access times to the agricultural fields highlights in terms of temporal access the fields located in the meadow and the first terraces of Mures and the main tributaries: Sebes, and Ighiu. For these surfaces, small access times were calculated within 0-60 minutes as access time to the main selling centers: Alba Iulia, Sebes and Teius.

Areas identified spatially with low access times are overlapping territorially with fields with high agricultural favourability, which makes this area to be considered the area with high potential for production and sales and is treated as a priority in terms of policy implementation for agricultural development in terms of rational exploitation and high efficiency of products obtained as a result of conforming cultivation.

It is highlighted that maximum access times (60-120 minutes) have been calculated for the low-favorability agricultural parcels located at the contact of the mountain with the area where the high favorability has been identified for another type of culture among which vineyard. This culture does not require short transport times to the market and secondary collection centers can be made in the respective areas and further sale in the form of engross for the high economic valorization of the production and, implicitly, of the less favorable agricultural land. Based on the access times, the territorial areas allocated as sales for each of the main centers were identified, was identified the center of Alba Iulia as the main hotspot in terms of the total surface area as sales and also in terms of assigned the agricultural parcels.

The analysis of access times for agricultural landings highlights the very short (less than 60 minutes) time needed to transport the harvested products to the main collection centers. At the same time, there were calculated high access times (120-300 minutes) for some parcels in the eastern part of the study area, for which it is proposed to set up secondary collection and selling centers in Engross regime.

Noteworthy is that integrated SWOT analysis of roadways in terms of exploitation for economical efficiency of agriculture in the studied area prove the good quality of the roads in the areas with high favorability but also good road quality that ensures fast transport (60 minutes maximum) between secondary collection centers and main sales centers showing the multiple ways to satisfy the demand for agricultural products on the consumer market.

The SWOT analysis of the general quality of the access network highlights qualitatively favourable territorial hotspots. When analysed in correlation with the areas with very low accessibility they highlight possible locations for collecting and temporarily storing the crops with the main purpose of maximising the profits on lots with maximum suitability and low accessibility.

The analysis of the complex and integrated GIS spatial analysis models, which focus on identifying the access time to production lots, gives useful information in the integrated management process (cultivation-production-storage-transport-sale) which has as its main purpose the maximising of profits for the exploitation of lands with maximum agricultural suitability.

Acknowledgement: All authors have equal contribution in the article. 


\section{R E F E R E N C ES}

Ajiboye, A. O. (1994) Rural Accessibility and Transportation Problems. A case study of Ijebu North Local Government Area, Ogun State'. Unpublished PGD in Transport Thesis, Department of Geography and Regional Planning, Ogun State University Ago-Iwoye.

Bilașco, Şt., Filip, S., Cocean, P., Petrea, D., Vescan, I. \& Fodorean, I. (2015) The Evaluation of Accessibility to Hospital Infrastructure at Regional Scale by using GIS Space Analysis Models: The North-West Region, Romania. Studia UBB Geographia, LX, 1, 27-50.

Bilaşco, St., Roşca, S., Păcurar, I., Moldovan, N., Boţ, A., Negruşier, C., Sestras, P., Bondrea, M. \& Naș, S. (2016) Identification of Land Suitability for Agricultural Use by Applying Morphometric and Risk Parameters Based on GIS Spatial Analysis. Not Bot Horti Agrobo, 2016, 44(1), $302-$ 312 Available from: doi:10.15835/nbha44110289 [Accessed 13 June 2017].

Blarel, B., Hazell, P., Place, F. \& Quiggin, J. (1992) The economics of farm fragmentation: Evidence from Ghana and Rwanda. World Bank Economic Review, 6 (2), 233-254. Available from: doi.org/10.1093/wber/6.2.233 [Accessed 20 June 2017].

Bobkova, M. \& Holesinska, A. (2017) Networking in a destination from the perspective of virtual relationships and their spatial dimension. Geographia Technica, 12 (2), 10-19. Available from: doi: 10.21163/GT_2017.122.02 [Accessed 1 August 2017].

Castella, J. C., Manh, P. H., Kam, S. P., Villano, L., \& Tronche, N. R. (2005) Analysis of village accessibility and its impact on land use dynamics in a mountainous province of northern Vietnam. Applied Geography, 25 (4), 308-326. Available from: doi:10.1016/j.apgeog.2005.07.003 [Accessed 4 June 2017].

Curtis, C. \& Scheurer, J. (2010) Planning for Sustainable Accessibility: Developing Tools to Aid Discussion and Decision-Making. Progress in Planning, 74, 53-106. Available from: doi: 10.1016/j.progress.2010.05.001[Accessed 24 August 2017].

Drobne, S. (2003) Modelling accessibility fields in Slovene municipalities, in L. Zadnik Sirn, M. Bastič, S. Drobne (eds.), Prooceedings of the 7th International Symposium on Operational Research in Slovenia. Slovenian Society Informatika (SDI), SOR, Ljubljana, 89-96.

Drobne, S., Bogataj, M., Paliska, D. \& Fabjan, D. (2005) Will the Future Motorway Network Improve the Accessibility to Administrative Centres in Slovenia? in: L. Zadnik Stirn, S. Drobne (eds.), Proceedings of the 8th International Symposium on Operational Research in Slovenia. Slovenian Society Informatika (SDI), SOR, Ljubljana, p. 213-218.

Dumitru, S., Mocanu,V., Ignat, P., Gherghina, A. \& Seleceanu, I. (2010) Land evaluation at farm level using GIS techniques. Analele Universităţii din Craiova, seria Agricultură, Montanologie, Cadastru 368-373.

Haidu, I. \& Nicoară, M. E. (2011) GIS Procedure for the identification of existing infrastructure in the flooding areas. Geographia Technica, 6 (2), 30-34.

Halder, J. C. (2013) Land suitability assessment for crop cultivation by using remote sensing and GIS. Journal of Geography and Geology 5 (3), 65-74. Available from: doi:10.5539/jgg.v5n3p65 [Accessed 27 July 2017].

Handy, S. L. \& Niemeier, D. A. (1997) Measuring Accessibility: an Exploration of Issues and Alternatives, Environment and Planning A, 29 (7), 1175-1194. Available from: doi.org/10.1068/a291175 [Accessed 29 July 2017].

Hartvigsen, M. (2016) Land consolidation in Central and Eastern Europe - integration with local rural development needs. World Bank Conference on Land and Poverty. The World Bank Washington DC, March 14-18, 2016.

Horvath, C.S (2008) Analiza SWOT a efectelor lacurilor de acumulare asupra mediului. model: amenajarea „Dragan-Iad” din bazinul superior al Crişului Repede. Geografia Napocensis, II, 2, 85-93. 
Iimi, A., Lancelot, E., Manelici, I. \& Ogita, S. (2015) Evaluating the Social and Economic Impacts of Rural Road Improvements in the State of Tocantins, Brazil. [Online] World Bank Group. Available from: http://hdl.handle.net/10986/22078 [Accessed 3 August 2017].

Ivan, K. \& Haidu, I. (2012) The Spatio-Temporal distribution of Road Accidents in Cluj-Napoca, Geographia Technica, 2, 32-38.

Jaarsma, C. F. (2000) Sustainable Land Use Planning and Planning of Rural Road Networks. Agricultural Engineering International: the CIGR Journal of Scientific Research and Development. Vol. II. Available from: https://ecommons.cornell.edu/bitstream/id/240/Land.PDF/ [Accessed 3 August 2017].

Janus, J. \& Taszakowski, J. (2015) The idea of ranking in setting priorities for land consolidation works. Geomatics, Land management and Landscape, 1, 31-43. Available from: doi.org/10.15576/gLL/2015.1.31 [Accessed 21 July 2017].

Janus, J., Bozek, P., Taszakowski, J. \& Glowacka, A. (2017). Road Accessibility Problem As Part Of Land Consolidation Planning. Engineering For Rural Development, 1052- 1056, Available from: doi: 10.22616/Erdev2017.16.N221. [Accessed 5 May 2017].

Julião, R. P. (1999) Measuring Accessibility Using GIS, in GeoComputation Proceedings, Available from: http://www.geovista.psu.edu/sites/geocomp99/Gc99/010/gc_010.htm.

Man, T., Rusu, R., Moldovan, C., Ionescu Heroiu, M., Moldovan, N.S. \& Haranguș, I. (2015) Spatial Impact Of The Road Infrastructure Development In Romania. An Accessibility Approach, Romanian Review of Regional Studies, XI (1), 101-112.

Moldovan, N., Păcurar, I., Roșca, S. \& Bilașco, Șt. (2016) Land Favorability To Crops In Intercommunity Association For Development Alba Iulia. Geographia Napocensis, X (1), 75-84.

Moldovan, N. (2016) Identificarea favorabilităţii optime a terenurilor la culturi agricole în contextul eficientizării economice a arealului Asociaţiei Intercomunitare de Dezvoltare Alba Iulia. $\mathrm{PhD}$ Thesis, USAMV Cluj Napoca.

Muntele, I., Groza, O., Țurcănașu, G, Rusu, Al. \& Tudora, D. (2010) The Quality of Transport Infrastructure as a Premise for Differentiating Rural Spaces in Moldavia "Al. I. Cuza" University Press, Iași.

Nicoară, M. E. \& Haidu, I. (2011) Creation of the roads network as a network dataset within a geodatabase. Geographia Technica, 6 (2), 81-86.

Nicoara, P. S. \& Haidu, I. (2014) A GIS based network analysis for theidentification of shortest route access to emergency medical facilities. Geographia Technica, 9 (2), 60-67.

Oprea, M. G. (2011) A Model for Calculating the Coefficient of Accessibility in the Transylvanian Administrative Territorial Units. Studia UBB Geographia, LVI (1), 167-174.

Păcurar, I. \& Buta, M. (2007) Soil and agricultural land evaluation marks (in Romanian). Ed Academic Pres, Cluj-Napoca.

Páez, A., Scott, M. A. \& Morency, C. (2012) Measuring Accessibility: Positive and Normative Implementations of Various Accessibility Indicators. Journal of Transport Geography, 25(11), 141-153. Available from: doi: 10.1016/j.jtrangeo.2012.03.016 [Accessed 5 April 2017].

Roșca, S. (2015a) Bazinul Nirajului Studui de Geomorfologie Aplicată. Risoprint Press, Cluj Napoca.

Roşca, S., Bilasco, Ş., Pacurar, I., Oncu, M., Negrusier, C., \& Petrea, D. (2015b) Land capability classification for crop and fruit product assessment using GIS technology. Case study: the Niraj River Basin (Transylvania Depression, Romania). Notulae Botanicae Horti Agrobotanici ClujNapoca 43 (1), 235-242. Available from: doi.org/10.15835/nbha4319860 [Accessed 21 October 2017].

Rusu, R., Man, T. \& Moldovan, S. C. (2013) The GIS-Based Road Distance and Time Connectivity Index of the Settlements within the West Region of Romania. Studia UBB, Seria Geographia, 141-150.

Thapa, R. B. \& Murayama, Y. (2008) Land evaluation for peri-urban agriculture using analytical hierarchical process and geographic information system techniques: A case study of Hanoi. Land 
use policy, 25(2), 225-239. Available from: doi: 10.1016/j.landusepol.2007.06.004 [Accessed 20 December 2017].

Van Diepen, C. A., Van Keulen, H., Wolf, J. \& Berkhout, J. A. A. (1991) Land evaluation: from intuition to quantification. In: Stewart BA (Ed). Advances in Soil Science. Springer, New York, 139-204.

Vega, A. (2012) Using Place Rank to Measure Sustainable Accessibility. Journal of Transport Geography, 24, 411-418. Available from: doi.org/10.1016/j.jtrangeo.2012.04.00 [Accessed 18 December 2017].

Wang, Q., Jin, X. \& Zhou, Y. (2010) A GIS-embedded system for land consolidation project location: Spatial optimization and fuzzy evaluation. 18th International Conference on Geoinformatics, Beijing, 2010, 1-6.

Wiggins, S. \& Proctor, S. (2001) How Special are Rural Areas? The Economic Implications of Location for Rural Development. Development Policy Review, 19(4), 427-436. 